\title{
UNUSUAL FEATURES OF THE MIDDLE DEVONIAN NARVA FORMATION COVERING THE OIL SHALE BEARING ROCKS IN ESTONIA
}

\author{
A. KLEESMENT*, A. SHOGENOVA, K. SHOGENOV \\ Institute of Geology \\ Tallinn University of Technology \\ 5 Ehitajate Rd, 19086 Tallinn, Estonia
}

\begin{abstract}
Mineral composition and properties of the Devonian carbonate rocks of Narva Regional Stage of NE Estonia, unconformably overlying the oil-shale bearing rocks of the Ordovician Kukruse Regional Stage, are discussed. Kerogen particles disintegrated from the kukersite-bearing Ordovician Viivikonna Formation due to erosion during the Late Silurian - Middle Devonian break in sedimentation and redeposited in lowermost layers of the Middle Devonian Vadja Formation. This allothigenic organic component specifically influenced the further diagenetic processes in the sediments. Star-like dolomite splays and needle-like crystals, chalcedony nodules, siderite and sulphide minerals of authigenic dolomite were formed. The presence of organic material and sulphur favoured for accumulation of total iron including $\mathrm{FeO}$. When compared with coeval rocks from South Estonia, these rocks differ also by decrease in grain and bulk density.
\end{abstract}

\section{Introduction}

In the course of mineralogical and petrophysical studies of the Devonian rocks, extraordinary signatures of authigenic mineralization were observed in the lowermost layers of Narva Regional Stage (RS) in the North East Estonia. The changes in the diagenetic mineralogies are probably caused by the Middle Devonian redeposition of kukersite oil shale kerogen from the Middle Ordovician layers under erosion into the basal Devonian layers. Regional uplift caused erosion during the Silurian-Devonian transition in the entire Baltic basin area, including that in the NE Estonia [1]. In the studied area west of the Narva River, in a local depression of the erosional surface of the Middle Ordovician rocks, the kukersite-bearing Viivikonna layers cropped out northerly and below the deposition area

\footnotetext{
*Corresponding author: e-mail kleesmen@gi.ee
} 
of the Vadja Formation (Fm; Figs. 1 and 2). Therefore, the probable source area of kerogen is located in the neighbourhood of the redeposition area [1].

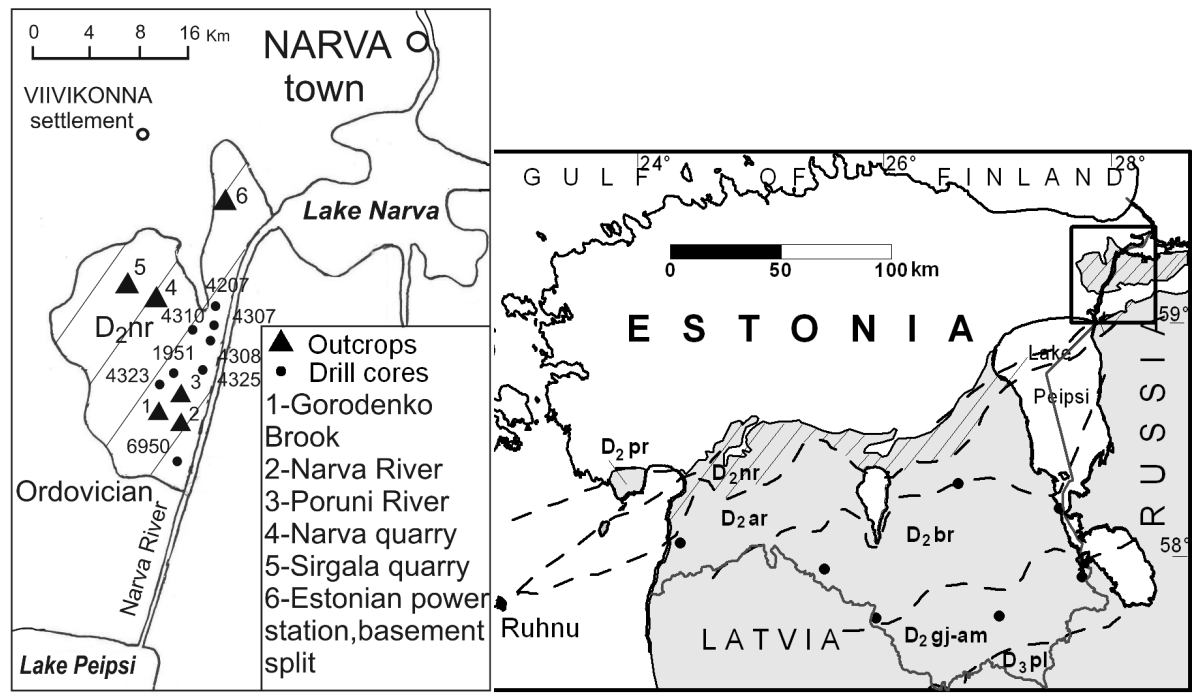

Fig. 1. Location of studied outcrops and drill cores in stratotype region (left) and in South Estonia.

In regional scale, the rocks of the Middle Devonian Narva Regional Stage are widespread in the East European Platform. Considering the palaeontological, lithological and mineralogical characteristics, the Narva RS has been subdivided into three substages/formations (Vadja, Leivu and Kernave), traceable from NE Estonia in the north up to eastern Belarus in the south $[2,3]$ and North-West Russia in the east [4]. These substages correspond to the acanthodian zones established by Valiukevičius [5]. The rocks of the Narva RS are exposed in several outcrops in NE Estonia (Fig. 1). The region on the left bank of the Narva River between Kuningaküla settlement and the Mustjõgi River is considered as a stratotype area of the Narva RS [2]. Natural outcrops of rocks occur at the Narva River and its tributes (Poruni River, Gorodenka Brook), and Narva and Sirgala oil shale quarries. All the three substages/formations of the Narva RS are exposed in the stratotype area. Rocks of the Vadja Formation (Fm) are visible in the outcrop on the left bank of the Narva River and in the sections of the Narva and Sirgala quarries, representing the whole section of the formation [6] (Fig. 2). Only the basal part of the Leivu Fm is exposed in the Narva River outcrop, and a small part of its upper half is exposed downstream on the Poruni River. 
The rocks, corresponding to the upper, Kernave Fm, crop out on the banks of the Gorodenka Brook and Poruni River, where there occur the sandstones and siltstones, characterizing this formation in Estonia and North Latvia [7, 8].

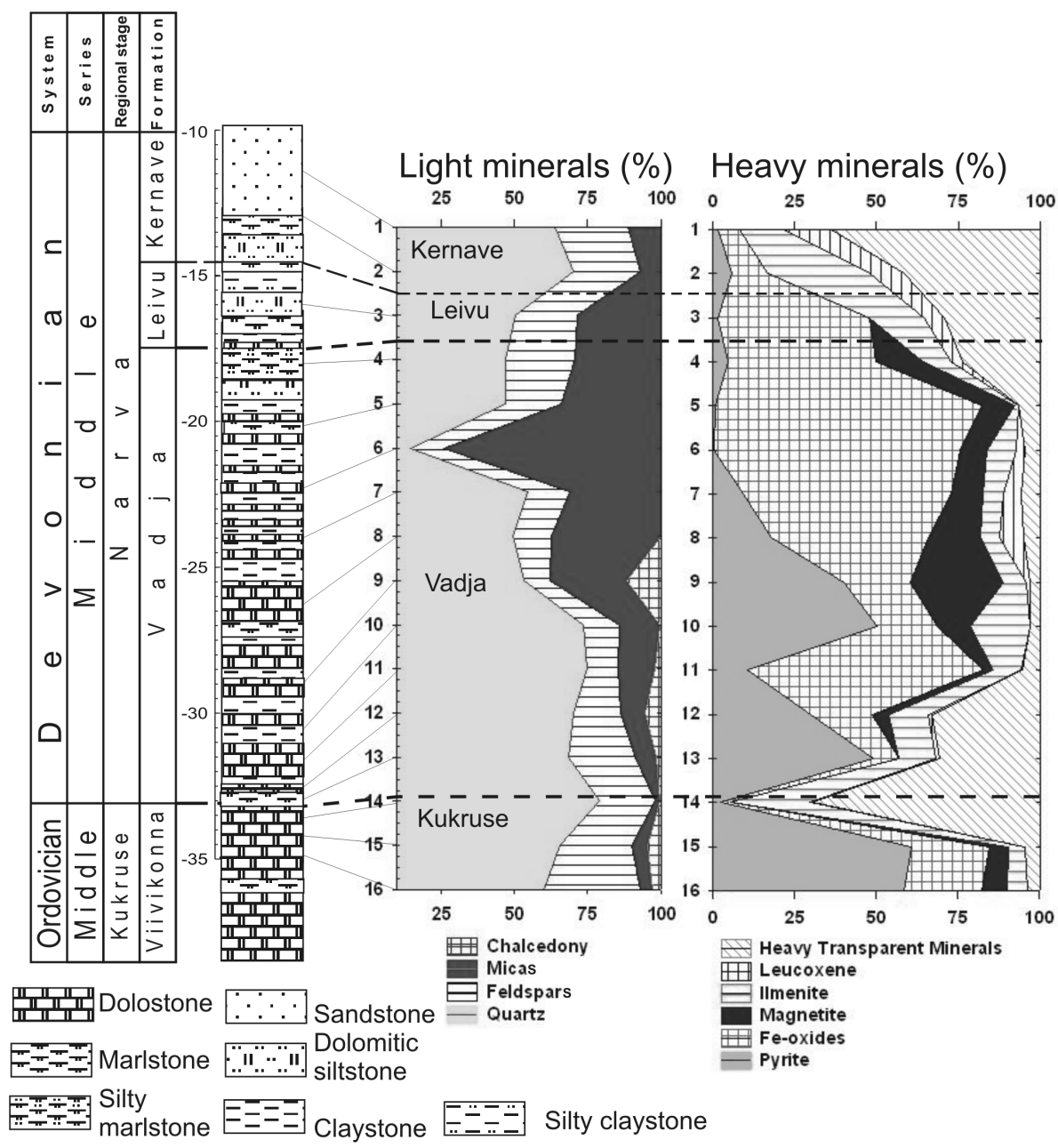

Fig. 2. Composed section with the stratigraphic column [10,121] of the stratotype region and mineral composition of $0.05-0.1$ fraction (95 samples). Correlative layers $1-16$. Kerogen-rich material occurs in the layer 13. Legend for minerals is given in sequence from right to left.

In the course of oil shale exploration numerous boreholes were drilled through the section of the Narva RS, eight of which were used for the present study together with rock samples from four outcrops (Fig. 1). 
Samples from eight South Estonian drill cores [8-11] were used for comparison. The Narva RS crops out in NE Estonia and the northern part of the Leningrad Region, while elsewhere it is mainly covered by younger rocks [7]. The studied rock succession of the Vadja Fm of the Narva RS, which is especially complete in NE Estonia, often lies on the Ordovician oil shale-bearing Viivikonna Formation (Fm) of the Kukruse RS [12] with a sedimentation break of more than 60 millions years. Our study is focused mainly on the Vadja Fm, because the impact of the redeposited oil shale kerogen was determined only in these rocks.

The influence of organic matter and/or sulphides on authigenic mineralization resulting in the formation of unusual features similar to those recorded by the present study have been discussed by many researchers [13-16]. It has been shown that decomposition of organic matter and sulphate-reducing bacteria can alter $\mathrm{pH}$ and mediate authigenic mineralization [17-21]. Organic substrates may also serve as nucleation sites for mineralization [13-22]. However, the complicated geological conditions and resultant authigenic mineral structures described in these publications resemble, but do not equal those determined and described in the present study.

\section{Material and methods}

All the natural outcrops of the stratotype area, Narva and Sirgala oil shale quarries, basement split for the Estonian electric power station and eight drill cores were studied. The grain size and mineral composition of the $0.05-0.1 \mathrm{~mm}$ fraction of 95 samples were investigated. The mineral composition was determined in immersion liquids under a microscope using plane-and cross-polarized, transmission light (PM). Muddy particles $(<0.01 \mathrm{~mm})$ of 31 samples were studied by X-ray diffraction (XRD) using HZG4 diffractometer (Fe filtered Co-radiation). For these analysis sample powders were mixed with alcohol and spread on glass slides. A range from 5 to $40^{\circ} 2 \theta$ was step-scanned (step $0.05^{\circ} 2 \theta$, counting rate $3 \mathrm{~s}$ ). Additionally sulphide minerals of 5 samples were analysed by XRD. The composition and structure of the rocks were studied in 65 thin sections under the PM with the magnification of up to 200 times. The needle-like and spherical features in thin sections were investigated under the scanning electron microscope and optical microscope Nixon Microphot-Fx, and the elemental composition of these forms was determined using the energy dispersive spectrum (EDS) analyser Link analytical AN-10000. Later investigations were carried out at the laboratory of the Centre of Materials Technology at Tallinn University of Technology (TUT).

The chemical composition of 15 samples from the Narva region and 69 samples of dolostones and dolomitic marlstones from South Estonian 
boreholes was measured by X-ray-fluorescence analysis in the All-Russian Geological Institute, St. Petersburg. Wet chemical analyses of the insoluble residue (IR) and $\mathrm{FeO}$ contents of the same samples (15 and 69) were made in the Institute of Geology (IG) at Tallinn University of Technology (TUT). Density and porosity of the 15 samples from NE Estonia were measured on cubes of $24 \mathrm{~mm}$ side using the water saturation method in the IG TUT [12]. Porosity and density of the 69 South Estonian rocks were measured at room temperature and pressure in the laboratories of the Geological Survey of Finland on samples of $50-200 \mathrm{~cm}^{3}$ size [23], in the Petrophysical Laboratory of the Research Institute of Earth's Crust of St. Petersburg University on cubes of $24 \mathrm{~mm}$ side $[24,25]$ and in the University of Helsinki on cubes of $24 \mathrm{~mm}$ side by the water saturation method [12].

Chemical and physical parameters were interpreted using correlation analysis.

\section{Results}

\section{Lithology and petrography}

The thickness of the Narva RS rocks in the studied stratotype area is up to $28 \mathrm{~m}$. The composite section of the Narva RS was created taking into account all available data from both drill cores and outcrops (Fig. 2). The average thickness of the siliciclastic sediments of the Kernave Fm is 7-10 m and of the Leivu Fm 4.7-7 m. The latter formation is represented by a thinlaminated complex of dolomitic marlstones, siltstones, claystones and dolostones. The lower, Vadja Fm is represented by a thin-bedded $16-20 \mathrm{~m}$ thick complex of alternating light grey and yellowish dolostone, grey dolomitic marlstone and dark grey claystone (Kuningaküla 6950 drill core, 12.7-28.9 m; Gorodenka 6951 drill core, 10.7-28.1 m). In outcrops the Vadja Fm occurs in a nearly complete thickness. In the Narva quarry the lower $8.7 \mathrm{~m}$ and in the basement split for the Estonian electric power station the lower $7 \mathrm{~m}$ are exposed. The upper $5.2 \mathrm{~m}$ of the Vadja $\mathrm{Fm}$ and the boundary with the unconformably overlying Leivu Fm are exposed in the Narva River outcrop (Fig. 1).

The topmost part of the underlying Viivikonna Fm is represented by grey and mottled aphano- to finely crystalline dolostone or dolomitic marlstone containing abundant recrystallized carbonate fossils (30-60\%) with tiny pyrite crystals along their structural elements. Detrital grains $(0.03-0.1 \mathrm{~mm})$, predominantly quartz, are found in matrix or are concentrated in pockets and patches. Rock is thin- and wavy-bedded. Small vugs and pyrite concentrations occur in some places along bedding surfaces. Some interbeds are enriched with kerogen. The fossil-rich limestone prevailing in the Kukruse RS appears 1-12 m below the Ordovician-Devonian contact.

The section of the Vadja Fm begins usually with a thin layer of dark-grey clay up to $10 \mathrm{~cm}$ thick in separate pockets. This layer is overlain by 
0.1-0.2 m of slightly silty dolostone or breccia-like dolomitic marl, followed by two $0.1-0.2 \mathrm{~m}$ thick layers of peculiar dark brown to black dolostone or claystone which consist of redeposited kerogen and are separated from each other by a $0.2-1,0 \mathrm{~m}$ layer of thin-bedded platy dolostone. This complex is overlain by a $1.2-1.8 \mathrm{~m}$ thick layer of thin-bedded dolostones. Upsection follows a clayey complex including $0.9-1.2 \mathrm{~m}$ thick interlayers of dolostone, covered by a 5-6 m thick alternating complex of dolostone and dolomitic marlstone with abundant fine layers of dark grey clay. The topmost $8-10 \mathrm{~m}$ of the section is represented by intercalating dolomitic marlstone (dominating) and dolostone containing some siltstone interbeds (Fig. 2).

The dolostone and dolomitic marlstone are mainly aphanocrystalline, rarely very finely crystalline. Medium-crystalline, often cavernous dolomitic rocks occur only in the basal part of the Devonian section. The microstructure is often wavy laminated (Fig. 3, a, b, e) and sometimes brecciated. The matrix includes scattered crystals of pyrite and hematite and the rock is penetrated by complicated branching fractures and vugs. Detrital grains, mainly $0.01-0.06 \mathrm{~mm}$, sometimes up to $0.2 \mathrm{~mm}$ in size, are often concentrated along bedding surfaces; sometimes detrital-rich pockets occur in cloudy dolomitic matrix.

The dolomitic rocks are often brownish, penetrated by thin wavy kerogen-rich layers (Fig. 3a-c, e). Two peculiar dark brown to black interlayers of dolomitic claystone or inequigranular silty dolostone are found in the lower part of all sections in which cloudy very finely crystalline dark brown and transparent light brown wavy laminae $(0.1-0.8 \mathrm{~mm})$ alternate. Transparent medium- to coarse-crystalline dolomite rhombs with welldeveloped faces and cleavage surfaces occur in transparent laminae of semitransparent fine-crystalline matrix. In addition to coarse-crystalline dolomite rhombs $(0.1-0.8 \mathrm{~mm})$, kerogen-rich interbeds contain abundant needle-like dolomite crystals (Fig. 3a). Commonly the needle-like crystals are $0.01-0.02 \mathrm{~mm}$ wide and $0.1-0.3 \mathrm{~mm}$ long, often forming ray-crystal splays (shrubs) with a diameter of $0.15-0.25 \mathrm{~mm}$ between dark brown kerogen-rich thin laminae (Fig. 3a-c, e-f), sometimes on authigenic dolomite crystals (Fig. 3a). Chemically the needles in ray-crystal shrubs are composed of pure dolomite, while the dolomite rock matrix contains also $\mathrm{Si}$, Al, K and Fe (Fig. 4). 


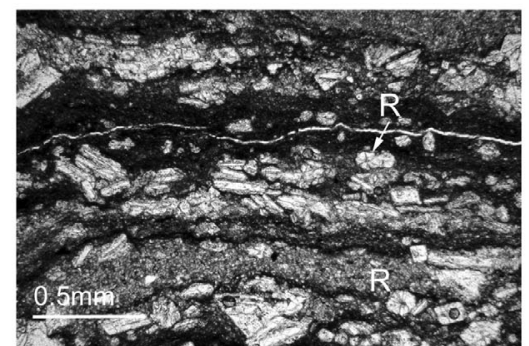

a

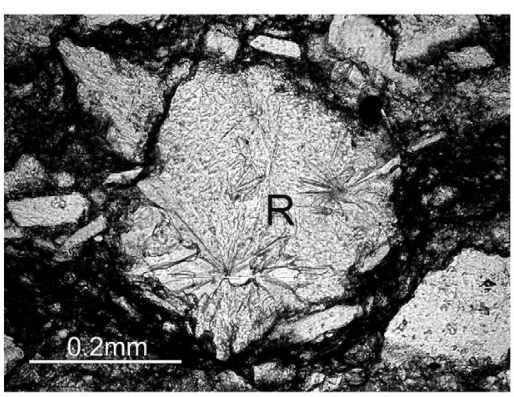

C

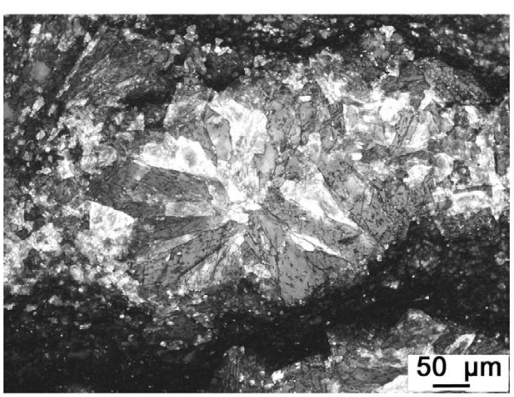

e

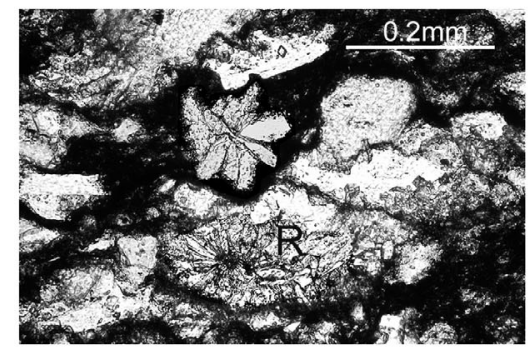

b

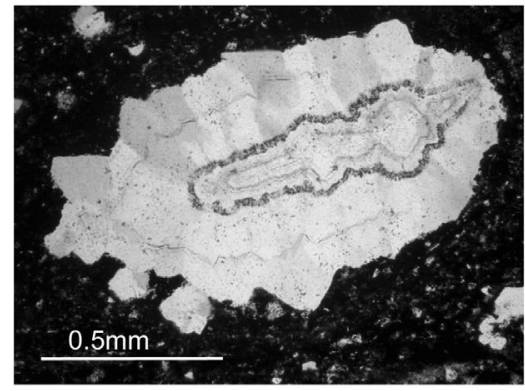

d

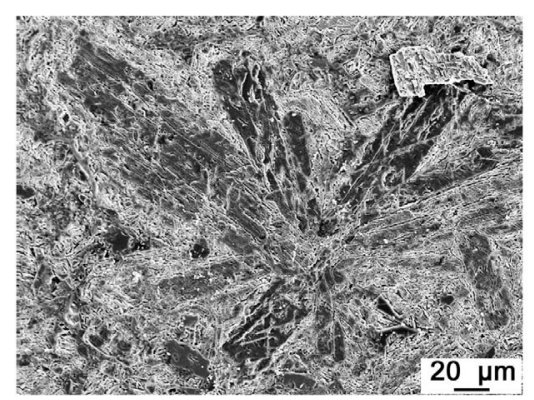

f

Fig. 3. Thin sections of rocks of Vadja Formation (a-f), plane polarized light. a) Inequigranular lenticular-wavy bedded dolostone. Alternating semitransparent matrix of fine crystalline and transparent medium to coarse crystalline laminae. Transparent dolomite rhomb has mainly well developed faces and cleavage surfaces. Abundant needle-like dolomite crystals are often placed on the rhombic dolomite crystals. In addition ray-crystal splays (shrubs) of fibrious dolomite crystals occur (R, arrow). Dark laminae are penetrated by kerogen-rich material, Narva quarry, sample 403; b) Kerogenrich inequigranular lenticular-wavy bedded dolostone containing dolomitic ray-crystal splays (shrubs) (R) in coarse grained laminae surrounded by kerogen-rich wavy surfaces, drill core 4325 , depth $28.8 \mathrm{~m}$; c) Coarse crystalline dolomite interbed surrounded by kerogen-rich wavy surfaces. Ray-crystal splays (shrubs) on the dolomite crystal (R). Drill core 4325, depth $28.8 \mathrm{~m}$; d) Chalcedony nodule in kerogen-rich dolostone showing concentric growth bands. Drill core 4207, $12.3 \mathrm{~m}$.

Ray-crystal splays (shrubs) in optical microscope Nixon Microphot-Fx (OM, e) and SEM (f). In OM surrounding dark kerogen-rich wavy laminae could be seen. Narva quarry, sample 403. 



Fig. 4. Comparative distribution of some chemical elements in fibrous crystal of a ray-crystal splay (shrub) and in matrix determined by EDS analyser along the marked line. Narva quarry, sample 403 , argillaceous dolostone $(20,5 \%$ IR by wet chemical analysis).

\section{Mineralogy}

The basal part of the Devonian section (thickness 2-5 m) contains siderite, authigenic chalcedony and sulphide minerals (major pyrite and minor sphalerite, galenite, chalcopyrite and marcasite). Chalcedony is present also in the topmost part of the Viivikonna Fm (Fig. 2). The black or dark brown dolostone described above is especially rich in authigenic chalcedony, but contains also abundant sulphide minerals, including galenite, which was not found in the other levels of the Devonian. Chalcedony occurs as flattened or spherical nodules $(0.1-0.6 \mathrm{~mm}$ in diameter and up to $1 \mathrm{~mm}$ long) with irregular outlines and embayments and concentric structure (Fig. 3d).

The detrital component of the rocks of the Vadja Fm is mainly arenite, containing quartz $50-65 \%$, feldspars $15-25 \%$ and micas $5-30 \%$ (Fig. 2). The 
rock of the upper part of the formation is often micaceous, but rich in quartz (75-80\%) in uppermost part of the Ordovician and basal part of the Devonian. Heavy fraction in this boundary level contains considerable amounts of transparent heavy minerals, mainly zircon, magnetite is not found. Usually iron hydroxides or pyrite dominate among heavy minerals and high quantities of magnetite are found in the upper half of the section (Fig. 2). Transparent heavy minerals (1-5\% of heavy fraction) are commonly dominated by garnet (20-70\%), but considerable amounts of unstable amphiboles and pyroxenes (up to 50\%) are present in the upper part of the section. Zircon accounts for 10-40\% throughout the section, whereas tourmaline and apatite are of secondary importance. The muddy fraction $(<0.01 \mathrm{~mm})$ is mainly represented by illite and chlorite, sometimes as mixed layers of montmorillonite-chlorite, illite-smectite, illite-chlorite and illitemontmorillonite.

\section{Chemical composition}

The bulk chemical composition of the 11 Devonian samples from the Narva region is in the same range as that of Devonian carbonate rocks of South Estonia [8, 9] (Fig. 5a). Samples of the Ordovician dolostone and dolomitic marlstone from the Kukruse RS have the bulk chemical composition in the same range as of Devonian dolomitized rocks.

The main difference in the chemical composition was observed in the percentage of $\mathrm{Fe}_{2} \mathrm{O}_{3}$ total and $\mathrm{FeO}$ (Figs. 5b, c) and in $\mathrm{FeO}-\mathrm{MnO}$ correlation (Fig. 5d). One Devonian dolostone sample from the Narva region showed relatively high contents of $\mathrm{Fe}_{2} \mathrm{O}_{3}(2.05 \%)$ and $\mathrm{FeO}(0.61 \%)$; in some other dolostones either $\mathrm{FeO}$ or $\mathrm{Fe}_{2} \mathrm{O}_{3}$ content was higher than in the Devonian dolostones of South Estonia. On average the $\mathrm{Fe}_{2} \mathrm{O}_{3}$ total $/ \mathrm{Al}_{2} \mathrm{O}_{3}$ ratio (0.89) and $\mathrm{FeO}$ content $(0.3 \%)$ are higher and the $\mathrm{Fe}_{2} \mathrm{O}_{3} / \mathrm{FeO}$ ratio (6.6) is lower in the dolostones and dolomitic marlstones of the Narva area. The lowest $\mathrm{Fe}_{2} \mathrm{O}_{3} / \mathrm{FeO}$ ratio (2.48) was determined in the limestone of the Viivikonna Fm of the Kukruse RS. The highest $\mathrm{Fe}_{2} \mathrm{O}_{3} / \mathrm{FeO}$ ratio (2.98-55, on average 17,5) was determined in the Devonian dolostones of South Estonia. In South Estonian rocks the average $\mathrm{Fe}_{2} \mathrm{O}_{3}$ total $/ \mathrm{Al}_{2} \mathrm{O}_{3}$ ratio (0.68) and $\mathrm{FeO}$ content $(0.13 \%)$ were lower; total iron content had high positive correlation with $\mathrm{Al}_{2} \mathrm{O}_{3}$, significant correlation with other components entering the insoluble residue $\left(\mathrm{SiO}_{2}, \mathrm{TiO}_{2}, \mathrm{~K}_{2} \mathrm{O}\right)$ and high negative correlation with $\mathrm{MgO}$ and $\mathrm{CaO}$. Such correlations were not detected in samples from the NE Estonia.

The average $\mathrm{MnO}$ content was lower in the Devonian rocks of the Narva region than in South Estonia, but in general the corresponding values were in the same range. Ordovician limestone and one Ordovician dolostone were low in $\mathrm{MnO}$ (Fig. 5d). The $\mathrm{Fe}_{2} \mathrm{O}_{3} / \mathrm{FeO}$ ratio was lower in the Ordovician samples than in the Devonian rocks (Fig. 5c). Strong positive correlations of $\mathrm{Mn}$ content with $\mathrm{FeO}$ content $(\mathrm{R}=0.86)$ and with the $\mathrm{Fe}_{2} \mathrm{O}_{3}$ total $/ \mathrm{Al}_{2} \mathrm{O}_{3}$ ratio $(\mathrm{R}=0.87)$ were determined for the Devonian rocks of the Narva region, but not for the South Estonian rocks. 

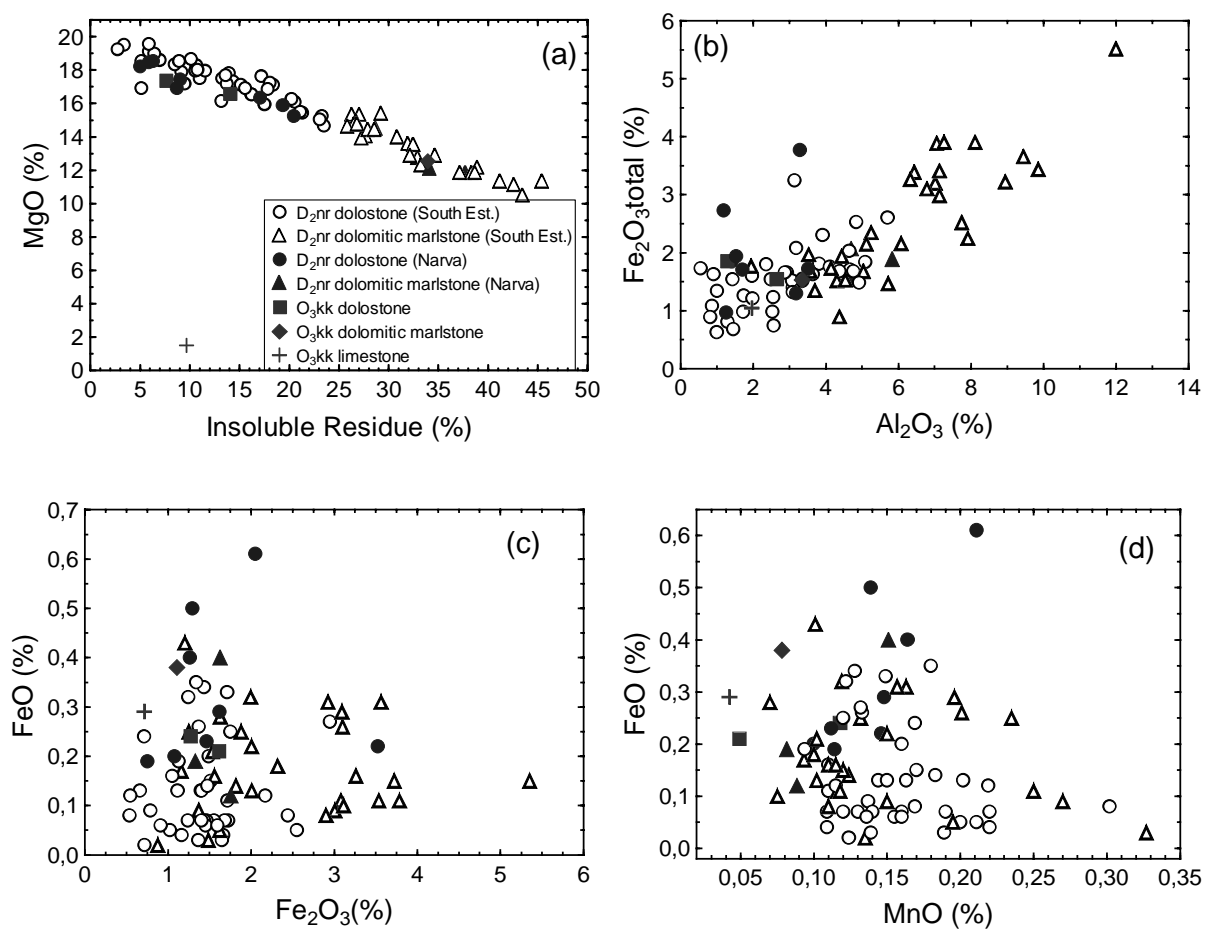

Fig. 5. a) $\mathrm{MgO}$ versus insoluble residue. Correlation coefficient $\mathrm{R}=-0.97$ for South Estonian rocks, $\mathrm{R}=-0.98$ for Devonian rocks from Narva region, (b) $\mathrm{Fe}_{2} \mathrm{O}_{3}$ total versus $\mathrm{Al}_{2} \mathrm{O}_{3}$ content, $\mathrm{R}=0.85$ for South Estonian rocks, no correlation was determined for rocks from NE Estonia, c) $\mathrm{FeO}$ versus $\mathrm{Fe}_{2} \mathrm{O}_{3}$ content, d) $\mathrm{FeO}$ versus $\mathrm{MnO}$ content, $\mathrm{R}=0.86$ for NE Estonian rocks.

\section{Density and porosity}

The rocks from the Narva region had a higher porosity and lower grain and bulk density than the Devonian rocks of South Estonia. The average grain density of South Estonian dolostone was $2.83\left(10^{3} \mathrm{~kg} / \mathrm{m}^{3}\right)$ and of marlstone $2,8\left(10^{3} \mathrm{~kg} / \mathrm{m}^{3}\right)$. The respective values were $2.79\left(10^{3} \mathrm{~kg} / \mathrm{m}^{3}\right)$ and $2.73\left(10^{3} \mathrm{~kg} / \mathrm{m}^{3}\right)$ for the dolostone and marlstone of NE Estonia. The average grain density of Ordovician dolostones was lower than that of Devonian rocks (Fig. 6a). The average porosity of South Estonian dolostones was $10.5 \%$ and of marlstones $14.9 \%$, while in NE Estonian rocks it was $13.5 \%$ in both rock groups (Fig. $6 \mathrm{~b}$ ). The average bulk density of the dolostones and marlstones of South Estonia was $2.64\left(10^{3} \mathrm{~kg} / \mathrm{m}^{3}\right)$ and $2.54\left(10^{3} \mathrm{~kg} / \mathrm{m}^{3}\right)$, while in the Narva region these values were $2.55\left(10^{3} \mathrm{~kg} / \mathrm{m}^{3}\right)$ and $2.52\left(10^{3} \mathrm{~kg} / \mathrm{m}^{3}\right)$ respectively. It should be mentioned that one dolostone sample from the Narva region (Sirgala quarry) contained open vugs and caverns (1-3 mm and more) and thus its porosity (15.9\%) could be underestimated by the water saturation method. 

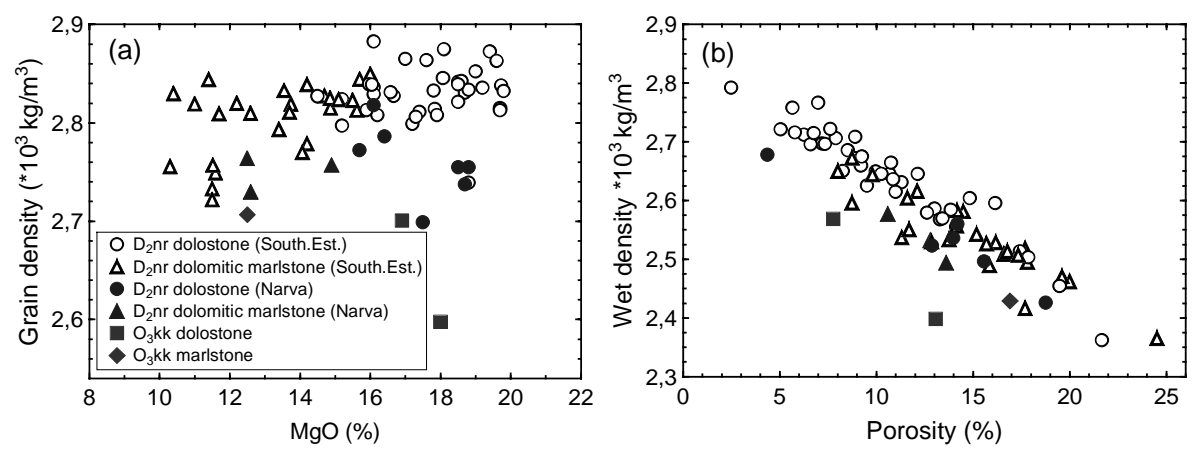

Fig. 6. a) Grain density versus $\mathrm{MgO}$ content, b) Wet density versus porosity in Devonian carbonate rocks. $\mathrm{R}=-0.93$ for South Estonian and $\mathrm{R}=-0.89$ for $\mathrm{NE}$ Estonian rocks.

\section{Discussion}

The dolomitic and muddy rocks of the Vadja Fm were formed in a shallow sea basin with brackish water conditions [26]. The influx of muddy and siliciclastic component took place across the Ordovician outcrop as verified by finds of redeposited Ordovician conodonts and crinoidal stem fragments at $8 \mathrm{~m}$ above the Ordovician-Devonian contact. Two dark brown to black dolostone-claystone interbeds occur in all similar redeposited kerogenbearing layers in the lower part of the section, however, the content of organic component in the rocks is low (about 3\%). The dark lenticular-wavy laminated dolostone with alternating fine-crystalline and coarse-crystalline laminae (Fig 3a-c) has some special features. Abundant needle-like and fibrous crystals, often forming ray-crystal splays (shrubs) are found in coarsecrystalline laminae related to kerogen-rich material (Fig. 3a-c, e). Such macro- and microstructures in carbonate sections have been described as uncommon (unique) features connected with sedimentation in complicated environmental conditions in a supersaturated shallow tropical basin of bacterially induced and rich in biota precipitation areas [13-16, 18, 22] or in hot-water travertine deposits [17]. They are commonly related to the replacement of calcite or dolomite by aragonite or, on the contrary, with the replacement of aragonite by calcite or dolomite. More rarely such structures have been explained by diagenesis. First the fibrous and concentric calcite (or dolomite) crystals that formed during diagenesis by the replacement of aragonite in carbonate rocks were described only around fossil centres of carbonate fossils $[13,22]$. Further they were found also in other environments. However, organic-rich material, in some cases also sulphur are necessary for the formation of carbonate needles [19, 27-29].

Needle-like crystals and ray-crystal splays (shrubs) occur in the Vadja rocks only in coarse-crystalline laminae recrystallised during diagenesis (Fig. 3a-c; e, f). They are composed of relatively pure dolomite, while the 
surrounding matrix contains various admixtures (Fig. 4). Sulphide minerals are also abundant in this level (Fig. 2). Morphologically the formations in the Vadja rocks resemble most of all the structures described in the petroleum-bearing deposits of the Zechstein limestone [21,29] and macrostructures $(2-10 \mathrm{~cm})$ of antraconite in Ordovician graptolitic argillite (Dictyonema Shale) of Estonian [30]. Spherical and filamentous features in oil shales have briefly been described in the Green River section in the USA [20]. Such features are not found in the well studied rocks of the underlying Kukruse RS.

The star-like dolomite splays and authigenic dolomite needle-like crystals in the Vadja rocks have a unique character and indicate specific conditions during diagenetic alteration processes. Possibly they were formed in early diagenesis by recrystallization of aragonite. The high salinity and high temperature conditions favouring the precipitation of aragonite existed during sedimentation of Vadja rocks, however, the basin was very poor in biota. The needed organic component was possibly provided by the redeposition of oil shale bearing material.

The studied dolomitic rocks of the Vadja Fm of NE Estonia differ from the similar rocks of South Estonia in a higher content of immature minerals (amphiboles, pyroxenes) and, in some cases, in a notable content of magnetite [8-11]. Siderite is a more common accessory mineral in $\mathrm{NE}$ Estonian rocks. Higher $\mathrm{FeO}$ contents and $\mathrm{Fe}_{2} \mathrm{O}_{3}$ total $/ \mathrm{Al}_{2} \mathrm{O}_{3}$ ratios in some samples show the increase in siderite, pyrite and magnetite as a result of diagenetic mineralization in the dolomitized rocks of the NE Estonia. Correlation of $\mathrm{FeO}$ with $\mathrm{MnO}$ also supports the occurrence of siderite, which commonly contains manganese. Concentric crystals of authigenic silica and chalcedony having some similar features with the above described chalcedony nodules with concentric structure and irregular outlines and embayments (Fig. 3d), have been found in bitumen-bearing dolomitic shales alternating with siliciclastic deposits and have been considered to form in a very early diagenetic phase, possibly mediated by sulphate-reducing bacteria [31].

Enrichment of the Devonian rocks with quartz, heavy fraction and transparent heavy minerals could be explained by weathering during transport and redeposition. The alteration process in the uppermost part of the Kukruse RS is more complicated. Recrystallization of carbonate matrix and carbonate fauna with pyrite took place in the upper part of the Ordovician in hard rock. The mineral composition of the detrital minerals in the upper $10 \mathrm{~cm}$ was a typical result of the weathering processes leading to high maturity of rocks with only very persistant minerals (zircon, tourmaline, ilmenite) preserved.

All rocks of the section have untergone diagenetic changes. During diagenesis the rocks were altered under the influence of several processes from mechanical compaction to chemical cementation. It could be supposed that the diagenetic process had some peculiar character in the dark brown 
(black) kerogen-bearing dolostone. Diagenetic influence and redeposition of kerogen in Devonian rocks changed their grain density, porosity and bulk density. The grain-density is usually in the range of $2.53-2.65\left(10^{3} \mathrm{~kg} / \mathrm{m}^{3}\right)$ in kerogen-bearing limestones of the Kukruse RS and in the range of 2.67$2.78\left(10^{3} \mathrm{~kg} / \mathrm{m}^{3}\right)$ in the dolostones, being lower than the grain density of the other carbonate rocks. The bulk density of the kerogen-bearing carbonate rocks is anomalously low as well $[12,25]$. The admixture of oil-shale reduced the grain density of Devonian dolostones and dolomitic marlstones. Other diagenetic processes, including the leaching of rocks associated with dolomitization, influence of weathering on exposed rocks, chemical reactions connected with the dissolution of minerals and chemical cementation, increased the porosity also in some South Estonian rocks [8]. Owing to lower grain density and higher porosity, the bulk density of the studied rocks of NE Estonia decreased.

\section{Conclusions}

1) Ordovician material had significant influence on the accumulation of the Devonian Vadja Formation rocks of NE Estonia.

2) Kerogen-rich admixture influenced the diagenetic processes, causing unusual mineralogical features and properties of the Devonian rocks.

3) Star-like dolomite splays, needle-like crystals of authigenic dolomite and chalcedony nodules were formed in complicated geological conditions in the presence of organic-rich material and sulphur with possible mediation by sulphate-reducing bacteria.

4) Chemical weathering of detrital grains and dolomitization took place also in hard rocks.

5) The mineral composition of NE Estonian Devonian rocks close to the Ordovician-Devonian border differs from that of South Estonian rocks in the enrichment in siderite, magnetite, sulphides (typical pyrite and rarer sphalerite, galenite, chalcopyrite and marcasite) and chalcedony.

6) Mineralogical differences are supported by increase in total iron and $\mathrm{FeO}$ and by the $\mathrm{FeO}-\mathrm{MnO}$ correlation not recorded for South Estonian Devonian rocks.

7) Decrease in grain density was caused by kerogen admixture. Increase in porosity resulted from diagenetic leaching, dissolution and recrystalization processes, which reduced the bulk density of NE Estonian rocks.

8) The obtained data provide valuable geological support for testing diagenetic models and redepositional processes of oil-shale containing rocks. 


\section{Acknowledgements}

This research was funded by the governmental target funding projects No. SF0332088s02 and No. SF0320080s07 from Ministry of Science and Education of Estonia and supported by the Estonian Science Foundation (grant No. 5726). The referees Prof. A. Raukas and Prof. V. Puura are thanked for the constructive reviews of the manuscript. We are grateful to our colleagues from Institute of Geology at Tallinn University of Technology (TUT), T. Linkova for wet chemical analysis, T. Kallaste for XRD analysis, Ü. Kestlane for thin-sections preparation and to G. Baranov for microphotographs of thin-sections. We thank V. Mikli from Centre for Materials Research at TUT operated SEM microscopy and EDS chemical analyses.

\section{REFERENCES}

1. Puura, V., Vaher, R., Tuuling, I. Pre-Devonian landscape of the Baltic Oil-Shale Basin, NW of the Russian Platform. Uplift, Erosion and Stability: Perspectives on long-term landscape development // Special Publication of London Geological Society 162. 1999. P. 75-83.

2. Valiukevičius, J. J., Kleesment, A. E., Kurik, E. J., Vaitekunene, G. K. Correlation and fossil remains of the deposits of the Narva Stage // Biofacies and fauna of East Baltic Silurian and Devonian sedimentation basins / A. P. Brangulis (ed.). Riga, Zinatne, 1986. P. 73-86 [in Russian].

3. Kleesment, A.-L., Kurik, E., Valiukevičius, J. On nomenklature of substages of the Narva Regional Stage // Proc. Acad. Sci. Estonian SSR. Geol. 1987. Vol. 36, No. 4. P. 174-175 [in Russian].

4. Valiukevičius, J. Acanthodian biostratigraphy and interregional correlations of the Devonian of the Baltic States, Belarus, Ukraine and Russia // Palaeozoic Vertebrate Biochronology and Global marine/Non-Marine Correlations / A. Blieck, S. Turner (eds). Frankfurt a. M.: Courier Forsch.-Inst. Senckenberg, 223, 2000. P. 271-289.

5. Valiukevičius, J. Acanthodians and zonal stratigraphy of Lower and Middle Devonian in East Baltic and Byelorussia // Palaeontographica, Abt. A. 1998, 248. P. 1-53.

6. Kleesment, A. Outcrops // Natural Monuments 13. Illuka, Mäetaguse, Iisaku, Alajõe / A. Miidel, A. Raukas (eds.). Tallinn: Estonian Academy Publishers, 2004. P. 16-19 [in Estonian].

7. Kleesment, A., Mark-Kurik, E. Devonian. Lower Devonian. Middle Devonian // Geology and Mineral Resources of Estonia / A. Raukas, A. Teedumäe (eds.). Tallinn: Estonian Academy Publishers, 1997. P. 107-121.

8. Kleesment, A., Shogenova, A. Lithology and evolution of Devonian carbonate and carbonate-cemented rocks in Estonia // Proc. Acad. Sci. Estonia. Geol. 2005. Vol. 54, No. 3, P. 153-180.

9. Shogenova, A., Kleesment, A. Diagenetic influences on iron-bearing minerals in Devonian carbonate and silicoclastic rocks of Estonia // Proc. Acad. Sci. Estonia. Geol. 2006. Vol. 55, No. 4, P. 269-295. 
10. Kleesment, A. Devonian // Ruhnu (500) drill core. Estonian Geological Sections 5 / A. Põldvere (ed.). Tallinn: Geological Survey of Estonia, 2003. P. 12.

11. Kleesment, A. Devonian // Mehikoorma (421) drill core. Estonian Geological Sections $6 /$ A. Põldvere (ed.). Tallinn: Geological Survey of Estonia, 2005. P. 10-13.

12. Shogenova, A., Shogenov, K., Donadini, F. Chemical composition and physical properties of the rock // Kerguta (565) drill core. Estonian geological sections 7 / A. Põldvere (ed.). Tallinn: Geological Survey of Estonia, 2006. P. 19-26.

13. Tucker, M. E., Kendall, A. C. The diagenesis and low-grade metamorphism of Devonian styliolinid-rich pelagic carbonates from West Germany: possible analogues of recent pteropod oozes // J. Sed. Petr. 1973. Vol. 43, No. 3. P. 672687.

14. Buszynski, C., Chafetz, H. S. Habit of bacterially induced precipitates of calcium carbonate and the influence of medium vicosity on mineralogy // J. Sed. Petr. 1991.Vol. 61, No. 2. P. 336-233.

15. James, N. P., Narbonne, G. M., Kyser, T. K. Late Neoproterozoic cap carbonates: Mackenzia Mountains, northwestern Canada: precipitation and global glacial mettdown // Canadian J. Earth Sci. 2001. Vol. 38. P. 1229-1262.

16. Fraiser, M. L., Corsetti, F. A. Neoproterozoic carbonate shrubs: interplay of microbial activity and unusual enviromental conditions in post-snowball earth oceans // Palaios. 2003. Vol. 18, No. 4. P. 378-387.

17. Chafetz, H. S., Guidry, S. A. Bacterial shrubs, crystal shrubs, and ray-crystal shrubs: bacterial vs. abiotic precipitation // Sed. Geol. 1999. Vol. 126, No. 1. P. 57-74.

18. Folk, R. L. Nannobacteria and the precipitation of carbonate in unusual environments // Sed. Geol. 1999. Vol. 126, No. 1. P. 47-55.

19. Peckmann, J., Paul, J., Thiel, V. Bacterially mediated formation of diagenetic aragonite and native sulfur in Zechstein carbonates (Upper Permian, Central Germany) // Sed. Geol. 1999. Vol. 126. P. 205-222.

20. Ma, Long, Chafetz, H. S. Microbially mediated dolomite associated with the oil shales of the lacustrine Green River Formation, Green River, Uinta, and Piceance Creek basins // Abstracts of $37^{\text {th }}$ Lunar and Planetary Science Conference. Houston, USA, 2006.

21. Chafetz H.S. Recognation of bacterially induced mineral precipitates: examples from carbonate, silicate, and $\mathrm{Mn}$ - and Fe-rich deposits // Abstracts of $37^{\text {th }}$ Lunar and Planetary Science Conference. Houston, USA, 2006.

22. Gevirtz, J. L., Friedman, G. M. Deep-sea carbonate sediments of the Red Sea and their implications of marine lithification // J. Sed. Petr. 1966. Vol. 36, No. 1. P. 143-151.

23. Jõeleht, A., Kukkonen, I. T. Physical properties of Vendian to Devonian sedimentary rocks in Estonia // GFF. 2002, 124. P. 65-72.

24. Prijatkin, A., Poljakov, E. Petrophysical methods of rocks study. - Leningrad: Leningrad University, 1983 [in Russian].

25. Shogenova, A., Puura, V. Petrophysical changes caused by dolomitization and leaching in fracture zones of lower Paleozoic carbonate rocks, North Estonia // Nordic Petroleum Technology Series: One. Second Nordic Symposium on Petrophysics, Fractured Reservoirs / Mike Middleton (ed.). Saghellinga, Norway: Nordisk Energi-Forskningsprogram, 1997. P. 155-185. 
26. Kleesment, A. Devonian sedimentation basin // Geology and Mineral Resources of Estonia / A. Raukas, A. Teedumäe (eds.). Tallinn: Estonia Academy Publishers, 1997. P. 205-208.

27. Yurkova, R. M. The use of epigenetic interlayer solution of some accessory minerals for establishing the time of formation of oil deposits // Epigenesis and its mineral indicators / A. G. Kossovskaya (ed.). Moskow: Nauka, 1971. P. 154-166 [in Russian)].

28. Laya, H. A., De La Pena, J. A., Benayas, J. Neoformed aragonite in clay soils on Keuper materials from east-central Spain// European J. Soil Sci. 1992. Vol. 43, No. 3. P. 401-407.

29. Peryt, T. M., Scholle, P. A. Regional setting and role of meteoric water in dolomite formation and diagenesis in an evaporite basin: studies in the Zechstein (Permian) deposits of Poland // Sedimentology. 1996. Vol. 43, No. 6. P. 1005-1023.

30. Mägi, S., Pirrus, E. Anthraconite and a giant concretion from Lasnamäe // Estonian Nature. 1978. No. 6. P. 392-394 [in Estonian].

31. Schieber, J. Early diagenetic silica deposition in algal cysts and spores: a source of sand and black shales? // J. Sed. Res. 1996. Vol. 66, No. 1, P. 175-183.

Presented by A. Raukas

Received June 12, 2007 